\title{
Nutritive and antioxidant characteristics of roasted leafy vegetables consumed in Western Côte d'Ivoire (Ivory Coast)
}

\author{
Armel Zoro, Lessoy Zoué*, Rose-Monde Megnanou, Gisèle Koua, Sébastien Niamké \\ Biotechnology Laboratory, Biosciences Faculty, Félix Houphouet-Boigny University, PO Box 582, Abidjan 22, Ivory Coast
}

Email address:

y.lessoy@yahoo.fr (L. Zoué)

\section{To cite this article:}

Armel Zoro, Lessoy Zoué, Rose-Monde Megnanou, Gisèle Koua, Sébastien Niamké. Nutritive and Antioxidant Characteristics of Roasted Leafy Vegetables Consumed in Western Côte d'Ivoire (Ivory Coast). American Journal of BioScience. Vol. 2, No. 6, 2014 , pp. $196-202$. doi: 10.11648/j.ajbio.20140206.12

\begin{abstract}
African Leafy Vegetables (ALVs) have long been recognized as the cheapest and the most abundant potential sources of vitamins and minerals using for fighting against malnutrition. Five leafy vegetables (Abelmoschus esculentus, Celosia argentea, Ipomea batatas, Manihot esculenta and Myrianthus arboreus) that are used for sauce preparation in Western Côte d'Ivoire (Ivory Coast) were subjected to roasting in order to evaluate the effect of this non conventional processing method on their nutritive and antioxidant properties. This study showed that longer time (higher than 2 min) of roasting at $180-200^{\circ} \mathrm{C}$ caused negative impact with nutrient losses but positive impact by reducing anti-nutrients such as oxalates and phytates. The registered losses at 2 min of roasting were as follow: ash $(7.47-36.65 \%)$, proteins $(3.04-32.66 \%)$, vitamin C $(75-92.14 \%)$, carotenoids $(27.34-81.94 \%)$, oxalates $(3.84-10.89 \%)$ and phytates $(0.45-15.72 \%)$. Roasting processing of the studied leafy vegetables highlighted a significant increase (2.63 to $13.83 \%$ ) of polyphenols contents coupled with increasing of antioxidant activity. Moreover, after $2 \mathrm{~min}$ of roasting processing, the residual contents of minerals were: calcium $(202.45-542.06 \mathrm{mg} / 100 \mathrm{~g})$, magnesium $(123.73-467.43 \mathrm{mg} / 100 \mathrm{~g})$, potassium $(1209.85-3796.16 \mathrm{mg} / 100 \mathrm{~g})$, iron $(44.72-128.47 \mathrm{mg} / 100 \mathrm{~g})$ and zinc $(6.35$ $-40.13 \mathrm{mg} / 100 \mathrm{~g}$ ). All these results suggest that roasting processing (less than $2 \mathrm{~min}$ at $200^{\circ} \mathrm{C}$ ) may be used as valuable cooking method of leafy vegetables in order to minimize nutrient losses and to contribute efficiently to the food security of Ivorian population.
\end{abstract}

Keywords: Antioxidant Properties, Roasting Processing, Leafy Vegetables, Nutritive Value

\section{Introduction}

Knowledge of African Leafy Vegetables (ALVs) and their uses is crucial for the survival of many African communities because they can serve as affordable sources of micronutrients and could contribute therefore to the reduction of malnutrition $[1,2,3]$. African leafy vegetables are better adapted to the environment than introduced exotic vegetables and also provide low-cost quality nutrition for large parts of the population in both rural and urban areas [4]. These plants have long been recognized as the cheapest and most abundant potential sources of vitamins and minerals. The ethno-botanical studies also report information on medicinal properties of ALVs like anti-diabetic, anti-histaminic, anti-carcinogenic, hypolipidemic and antibacterial activities [5]. Many African families who depend on traditional leafy vegetables use them as available and affordable feed when they are out of the vegetable production season [6]. Many different methods are adopted for the preservation of these leafy vegetables with sun-drying as the popular processing which removes the moisture from the food so bacteria, yeast and molds cannot grow and spoil [7]. Among the twenty hundred and seven (207) leafy vegetables widely consumed in tropical Africa, about twenty (20) species belonging to 6 botanical families, are widely consumed and cultivated by Ivorian populations [8,9]. Furthermore, ethno-botanical surveys have revealed that the consumption of these leafy vegetables is linked to cultural regions. Thus, most people in Western Côte d'Ivoire (Ivory Coast) consume through sauces preparation, leafy vegetables such as Abelmoschus esculentus "gombo", Celosia argentea "soko", Ipomea batatas "patate", Manihot esculenta "manioc" and Myrianthus arboreus "tikliti $[9,10]$. Earlier reports have highlighted the nutritive potential of these fresh leafy vegetables [11]. For these species, the 
tender leaves are prepared as potherbs or as relishes, primarily to accompany starchy paste foods as cassava, maize and sorghum. These leafy vegetables may be prepared from a single species or from a combination of them. For cooking, the mature and freshly leaves are boiled in water for about $30 \mathrm{~min}$ in order to reduce bitter taste and then used, after discarding boiled water, for sauce preparation. In a lesser extent, blanching is also used to inactivate oxidative enzymes, destroy vegetative microbial cells, reduce or eliminate the bitterness and to remove any residual pesticides [12,13]. Even if some adverse effects such as nutrient losses have been reported by using boiling or blanching processing [14,15], there is any data on the roasting (oven-cooking) processing effect on the physicochemical and nutritive properties of leafy vegetables consumed in Western Côte d'Ivoire (Ivory Coast). Therefore, the purpose of this study is to conduct investigation on the influence of roasting on the nutritive value of these selected leafy vegetables in order to provide necessary information for their wider utilization and contribution to food security of Ivorian population.

\section{Material and Methods}

\subsection{Samples Collection}

Leafy vegetables (Abelmoschus esculentus, Celosia argentea, Ipomea batatas, Manihot esculenta and Myrianthus arboreus) were collected fresh and at maturity from cultivated farmlands located at Dabou (latitude: 5'19'14" North; longitude: $4^{\circ} 22^{\prime} 59^{\prime \prime}$ West) (Abidjan District). The samples were harvested at the early stage (between one and two weeks of the appearance of the leaves). These plants were previously authenticated by the National Floristic Center (University Felix Houphouët-Boigny, Abidjan-Ivory Coast).

\subsection{Samples Processing}

The fresh leafy vegetables were rinsed with deionized water and the edible portions were separated from the inedible portions. The edible portions were chopped into small pieces $(500 \mathrm{~g})$ and allowed to drain at ambient temperature. Each sample was subdivided into two parts. One part (raw, $250 \mathrm{~g}$ ) was dried in an oven (Memmert, Germany) at $60^{\circ} \mathrm{C}$ for $72 \mathrm{~h}$ [16]. The dried leaves were ground with a laboratory crusher (Culatti, France) equipped with a $10 \mu \mathrm{m}$ mesh sieve. Each sample was stored in a clean dry air-tight sample bottle in a refrigerator $\left(4^{\circ} \mathrm{C}\right)$ until required for analyses. The second part $(250 \mathrm{~g})$ was roasted (oven-cooking) for 2, 4 and $6 \mathrm{~min}$ at $180-200^{\circ} \mathrm{C}$. The roasted samples were cooled at ambient temperature and subjected to the same treatment (drying and gridding) using for raw samples.

\subsection{Chemicals}

All solvents (n-hexane, petroleum ether, acetone, ethanol and methanol) were purchased from Merck. Standards used (gallic acid, $\beta$-carotene) and reagents (metaphosphoric acid, Folin-Ciocalteu, DPPH) were purchased from Sigma-Aldrich. All chemicals used in the study were of analytical grade.

\subsection{Nutritive Properties}

\subsubsection{Proximate Analysis}

Proximate analysis was performed using official methods [17]. The moisture content was determined by the difference of weight before and after drying fresh sample $(10 \mathrm{~g})$ in an oven (Memmert, Germany) at $105^{\circ} \mathrm{C}$ until constant weight. The dry matter content was deduced from the difference of 100 and percentage moisture. Ash fraction was determined by the incineration of dry matter sample $(5 \mathrm{~g})$ in a muffle furnace (Pyrolabo, France) at $550^{\circ} \mathrm{C}$ for $12 \mathrm{~h}$. The percentage residue weight was expressed as ash content. For crude fibres, $2 \mathrm{~g}$ of dry matter sample were weighed into separate $500 \mathrm{~mL}$ round bottom flasks and $100 \mathrm{~mL}$ of $0.25 \mathrm{M}$ sulphuric acid solution was added. The mixture obtained was boiled under reflux for $30 \mathrm{~min}$. Thereafter, $100 \mathrm{~mL}$ of $0.3 \mathrm{M}$ sodium hydroxide solution was added and the mixture were boiled again under reflux for $30 \mathrm{~min}$ and filtered through Whatman paper. The insoluble residue was then incinerated, and weighed for the determination of crude fibres content. Proteins were determined through the Kjeldhal method and the lipid content was determined by Soxhlet extraction using hexane as solvent. Carbohydrates content and calorific value were calculated and expressed on dry matter basis using the following formulas [18]:

Carbohydrates (dry matter basis):

$$
100-(\% \text { proteins }+\% \text { lipids }+\% \text { ash }+\% \text { fibres })
$$

Calorific value (dry matter basis):

$(\%$ proteins $\times 2.44)+(\%$ carbohydrates $x 3.57)+(\%$ lipids $x$ 8.37) $(2)$

The results of ash, fibres, proteins, lipids and carbohydrates contents were expressed on dry matter basis.

\subsubsection{Anti-Nutritional Factors Determination}

Oxalates content was performed by using a titration method [20]. One (1) g of dried powdered sample was weighed into $100 \mathrm{~mL}$ conical flask. A quantity of $75 \mathrm{~mL}$ of sulphuric acid (3 $\mathrm{M})$ was added and stirred for $1 \mathrm{~h}$ with a magnetic stirrer. The mixture was filtered and $25 \mathrm{~mL}$ of the filtrate was titrated while hot against $\mathrm{KMnO}_{4}$ solution $(0.05 \mathrm{M})$ to the end point.

Phytates contents were determined using the Wade's reagent colorimetric method [21]. A quantity (1 g) of dried powdered sample was mixed with $20 \mathrm{~mL}$ of hydrochloric acid $(0.65 \mathrm{~N})$ and stirred for $12 \mathrm{~h}$ with a magnetic. The mixture was centrifuged at $12000 \mathrm{rpm}$ for $40 \mathrm{~min}$. An aliquot $(0.5 \mathrm{~mL})$ of supernatant was added with $3 \mathrm{~mL}$ of Wade's reagent. The reaction mixture was incubated for $15 \mathrm{~min}$ and absorbance was measured at $490 \mathrm{~nm}$ by using a spectrophotometer (PG Instruments, England). Phytates content was estimated using a calibration curve of sodium phytate $(10 \mathrm{mg} / \mathrm{mL})$ as standard.

\subsubsection{Mineral Analysis}

Minerals contents were determined by the ICP-MS (inductively coupled argon plasma mass spectrometer) method [19].The dried powdered samples ( $5 \mathrm{~g}$ ) were burned to ashes in a muffle furnace (Pyrolabo, France). The ashes obtained were dissolved in $10 \mathrm{~mL}$ of $\mathrm{HCl} / \mathrm{HNO}_{3}$ and 
transferred into $100 \mathrm{~mL}$ flasks and the volume was made up using deionized water. The mineral composition of each sample was determined using an Agilent 7500c argon plasma mass spectrometer. Calibrations were performed using external standards prepared from a 1000 ppm single stock solution made up with $2 \%$ nitric acid.

\subsubsection{Antioxidant Properties Evaluation}

\subsubsection{Vitamin C and Carotenoids Determination}

Vitamin $\mathrm{C}$ contained in analyzed samples was determined by titration [22]. About $10 \mathrm{~g}$ of ground fresh leaves were soaked for $10 \mathrm{~min}$ in $40 \mathrm{~mL}$ metaphosphoric acid-acetic acid $(2 \%, \mathrm{w} / \mathrm{v})$. The mixture was centrifuged at $3000 \mathrm{rpm}$ for 20 min and the supernatant obtained was diluted and adjusted with $50 \mathrm{~mL}$ of bi-distilled water. Ten (10) $\mathrm{mL}$ of this mixture was titrated to the end point with dichlorophenol-indophenol (DCPIP) $0.5 \mathrm{~g} / \mathrm{L}$.

Carotenoids were extracted and quantified following a spectrophotometric method [23]. Two (2) g of ground fresh leaves were mixed three times with $50 \mathrm{~mL}$ of acetone until loss of pigmentation. The mixture obtained was filtered and total carotenoids were extracted with $100 \mathrm{~mL}$ of petroleum ether. Absorbance of extracted fraction was then read at $450 \mathrm{~nm}$ by using a spectrophotometer (PG Instruments, England). Total carotenoids content was subsequently estimated using a calibration curve of $\beta$-carotene $(1 \mathrm{mg} / \mathrm{mL})$ as standard.

\subsubsection{Polyphenols Determination}

Polyphenols were extracted and determined using Folin-Ciocalteu's reagent [24]. A quantity (1 g) of dried powdered sample was soaked in $10 \mathrm{~mL}$ of methanol $70 \%(\mathrm{v} / \mathrm{v})$ and centrifuged at $1000 \mathrm{rpm}$ for $10 \mathrm{~min}$. An aliquot $(1 \mathrm{~mL})$ of supernatant was oxidized with $1 \mathrm{~mL}$ of Folin-Ciocalteu's reagent and neutralized by $1 \mathrm{~mL}$ of $20 \%(\mathrm{w} / \mathrm{v})$ sodium carbonate. The reaction mixture was incubated for $30 \mathrm{~min}$ at ambient temperature and absorbance was measured at $745 \mathrm{~nm}$ by using a spectrophotometer (PG Instruments, England). The polyphenols content was obtained using a calibration curve of gallic acid $(1 \mathrm{mg} / \mathrm{mL})$ as standard.

\subsubsection{Antioxidant Activity}

Antioxidant activity assay was carried out using the 2,2-diphenyl-1-pycrilhydrazyl (DPPH) spectrophotometric method [25]. About $1 \mathrm{~mL}$ of $0.3 \mathrm{mM}$ DPPH solution in ethanol was added to $2.5 \mathrm{~mL}$ of sample solution $(1 \mathrm{~g}$ of dried powdered sample mixed in $10 \mathrm{~mL}$ of methanol and filtered through Whatman No. 4 filter paper) and was allowed to react for $30 \mathrm{~min}$ at room temperature. Absorbance values were measured with a spectrophotometer (PG Instruments, England) set at $415 \mathrm{~nm}$. The average absorbance values were converted to percentage antioxidant activity using the following formula:

Antioxidant activity $(\%)=100-[($ Abs of sample - Abs of blank) x 100/Abs positive control]

\subsubsection{Statistical Analysis}

All the analyses were performed in triplicate and data were analyzed using EXCELL and STATISTICA 7.1 (StatSoft). Differences between means were evaluated by Duncan's test. Statistical significant difference was stated at $\mathrm{p}<0.05$.

\section{Results and Discussion}

\subsection{Nutritive Properties}

The proximate composition of the roasted leafy vegetables is presented in Table 1. The described physicochemical parameters generally differ significantly $(\mathrm{p}<0.05)$ from a roasting time of a leafy vegetable to another. The ash content after 2 min of roasting ranged from $5.72 \pm 0.93 \%$ (M. esculenta) to $17.59 \pm 0.09 \%$ (I. batatas). These values were closed to 5.48 $\pm 0.15 \%$ (M. esculenta) and $16.18 \pm 0.57 \%$ (C. argentea) after $6 \mathrm{~min}$ of roasting. The decrease rate observed at $2 \mathrm{~min}$ of roasting ranged from 7.47 to $36.65 \%$ in the following order: $A$. esculentus $(7.47 \%)>M$. arboreus $(12.10 \%)>C$. argentea $(20.90 \%)>I$. batatas $(25.33 \%)>M$. esculenta $(36.65 \%)$. These observed losses are lower than that $(16.22-54.29 \%)$ reported for the same boiled leafy vegetables [26]. With regard to this minerals retention $(63.35-92.53 \%)$, roasting processing could be advantageous for mineral quality preservation of leafy vegetables. As regards protein contents, roasting processing resulted in 3.04 to $32.66 \%$ reduction after $2 \mathrm{~min}$. The lowest proteins content reduction (3.04\%) was observed for $A$. esculentus while the maximum reduction of proteins content (32.66\%) was noted for M. esculenta. The average reduction of proteins in this study is comparable to that $(4-33 \%)$ obtained in previous report for the same boiled leafy vegetables [26]. These losses in protein contents could be attributed to the severity of thermal processing $\left(180-200^{\circ} \mathrm{C}\right)$ which leads to protein degradation [27]. However, the studied thermal processing could enhance the digestibility of proteins by degradation of anti-nutritional factors such as tannins [28]. Roasting of the studied leafy vegetables resulted in increasing $(\mathrm{p}<0.05)$ in their crude fibres contents $(4.59-11.48 \%)$ after 2 min of heat application. Indeed, the increased temperature leads to breakage of weak bonds between polysaccharides and the cleavage of glycosidic linkages, which makes the dietary fibres soluble [29]. Considering the fibres contents (13.59 - 32.30\%) after $2 \mathrm{~min}$ of roasting, adequate intake $(100 \mathrm{~g} / \mathrm{day})$ of roasted leafy vegetables as desserts could lower the risk of constipation, diabetes, and colon cancer [30]. The relatively low values of lipids contents at 2 min of roasting $(1.87-3.95 \%)$ for the studied leafy vegetables corroborates the findings of many authors which showed that leafy vegetables are poor sources of fat [31]. Therefore, the daily consumption of roasted leafy vegetables through soup preparation could be advantageous for the prevention of lipid disorders as obesity. In addition, the calculated calorific values $(213.45-283.33 \mathrm{kcal} / 100 \mathrm{~g})$ after 2 min of roasting agrees with general observation that leafy vegetables have low energy values due to their low crude fat and relatively high level of moisture [32].

The impact of roasting on anti-nutritional factors (oxalates 
and phytates) contents is depicted in figure 1 . The observed losses at 2 min of roasting were $3.84-10.89 \%$ and $0.45-$ $15.72 \%$ for oxalates and phytates, respectively. Considering oxalates and phytates contents, the maximum reduction values (10.89 and $15.72 \%$ ) after 2 min of roasting were observed for A. esculentus. These reductions in oxalates and phytates contents during roasting are lower than that (19.63-67.47\%) of boiled leafy vegetables consumed in Western Côte d'Ivoire [26]. Oxalates and phytates are anti-nutrients which chelate divalent cations such as calcium, magnesium, zinc and iron thereby reducing their bioavailability [33]. In order to reduce considerably their oxalates and phytates contents, roasted leafy vegetables may be soaked before using as desserts.

\subsection{Mineral Composition}

Mineral composition of the studied roasted leafy vegetables is shown in table 2 . The residual contents of minerals after 2 min of roasting were significantly different $(\mathrm{p}<0.05)$ : calcium (202.45 - $542.06 \mathrm{mg} / 100 \mathrm{~g})$, magnesium (123.73 - 467.43 $\mathrm{mg} / 100 \mathrm{~g})$, potassium $(1209.85$ - $3796.16 \mathrm{mg} / 100 \mathrm{~g})$, iron $(44.72-128.47 \mathrm{mg} / 100 \mathrm{~g})$ and zinc $(6.35-40.13 \mathrm{mg} / 100 \mathrm{~g})$.
Compared to the values of raw and boiled leafy vegetables [26], these observed reductions may be due to the losses of ashes. With regard to these residual values, powdered roasted leafy vegetables could be recommended as food complement in porridges preparation for target populations as infants, pregnant woman and old people in order to cover mineral requirements. Indeed, the standard mineral requirements for human are: calcium (1000 mg/day); magnesium (400 mg/day), iron (8 mg/day) and zinc (6 mg/day) [34]. Calcium and phosphorus play important role in growth and maintenance of bones, teeth and muscles [35]. As regards magnesium, this mineral is known to prevent muscle degeneration, growth retardation, congenital malformations and bleeding disorders [36]. Iron plays important role in prevention of anemia while zinc is important for vitamin A and vitamin $\mathrm{E}$ metabolisms [37,34]. In order to predict the bioavailability of calcium and iron, anti-nutrients to nutrients ratios of roasted leafy vegetables were calculated (Table 3). The calculated [phytates]/[Ca] ratio in all the roasted species were below the critical level of 2.5 which is known to impair calcium bioavailability [38].

Table 1. Proximate composition of raw and roasted leafy vegetables consumed in Western Côte d'Ivoire.

\begin{tabular}{|c|c|c|c|c|c|c|}
\hline & $\operatorname{Ash}(\%)$ & Fibres (\%) & Proteins (\%) & Lipids (\%) & Carbohydrates (\%) & Energy (kcal /100g) \\
\hline \multicolumn{7}{|c|}{ A. esculentus } \\
\hline Raw & $11.90 \pm 0.10 \mathrm{a}$ & $15.66 \pm 0.05 b$ & $9.19 \pm 0.15 a$ & $3.38 \pm 1.59 \mathrm{a}$ & $59.87 \pm 1.90 \mathrm{a}$ & $264.44 \pm 2.51 b$ \\
\hline $2 \mathrm{~min}$ & $11.01 \pm 0.13 \mathrm{a}$ & $16.38 \pm 0.53 a$ & $8.91 \pm 0.00 \mathrm{a}$ & $3.38 \pm 0.00 \mathrm{a}$ & $60.34 \pm 0.53 a$ & $280.10 \pm 1.90 \mathrm{a}$ \\
\hline $4 \min$ & $10.18 \pm 0.35 b$ & $16.33 \pm 0.53 a$ & $8.90 \pm 0.92 a$ & $3.89 \pm 0.00 \mathrm{a}$ & $60.70 \pm 1.45 \mathrm{a}$ & $283.37 \pm 2.93 a$ \\
\hline $6 \mathrm{~min}$ & $9.96 \pm 0.64 b$ & $16.75 \pm 0.35 a$ & $8.53 \pm 0.91 \mathrm{a}$ & $3.22 \pm 0.00 \mathrm{a}$ & $61.54 \pm 1.56 \mathrm{a}$ & $282.92 \pm 0.23 \mathrm{a}$ \\
\hline \multicolumn{7}{|c|}{ M.esculenta } \\
\hline Raw & $9.03 \pm 2.12 \mathrm{a}$ & $26.23 \pm 0.31 \mathrm{a}$ & $23.39 \pm 0.71 \mathrm{a}$ & $4.09 \pm 0.02 b$ & $37.27 \pm 3.16 b$ & $224.35 \pm 5.67 \mathrm{a}$ \\
\hline $4 \mathrm{~min}$ & $5.57 \pm 0.17 b$ & $28.00 \pm 0.41 b$ & $15.75 \pm 0.00 b$ & $3.66 \pm 0.00 c$ & $47.02 \pm 1.56 \mathrm{a}$ & $229.35 \pm 5.56 a$ \\
\hline $6 \min$ & $5.48 \pm 0.15 b$ & $28.11 \pm 0.56 b$ & $15.03 \pm 0.93 b$ & $4.59 \pm 0.00 \mathrm{a}$ & $46.79 \pm 1.48 \mathrm{a}$ & $228.09 \pm 3.04 \mathrm{a}$ \\
\hline \multicolumn{7}{|c|}{ I. batatas } \\
\hline Raw & $23.56 \pm 2.13 a$ & $21.50 \pm 0.82 b$ & $15.52 \pm 0.40 \mathrm{a}$ & $2.63 \pm 0.06 c$ & $36.79 \pm 3.41 b$ & $232.91 \pm 5.78 b$ \\
\hline $2 \min$ & $17.59 \pm 0.09 b$ & $23.00 \pm 0.50 \mathrm{a}$ & $13.53 \pm 0.91 b$ & $3.52 \pm 0.00 \mathrm{a}$ & $42.36 \pm 1.41 \mathrm{a}$ & $240.13 \pm 1.90 \mathrm{a}$ \\
\hline $4 \min$ & $17.53 \pm 0.13 b$ & $23.75 \pm 0.50 \mathrm{a}$ & $13.18 \pm 0.95 b$ & $3.01 \pm 0.00 \mathrm{~b}$ & $42.53 \pm 1.55 \mathrm{a}$ & $243.37 \pm 2.93 a$ \\
\hline $6 \mathrm{~min}$ & $16.01 \pm 0.09 c$ & $24.12 \pm 0.54 \mathrm{a}$ & $13.22 \pm 1.95 b$ & $3.55 \pm 0.00 \mathrm{a}$ & $43.10 \pm 1.41 \mathrm{a}$ & $245.92 \pm 0.23 a$ \\
\hline $2 \min$ & $17.48 \pm 0.68 b$ & $32.30 \pm 0.97 b$ & $9.14 \pm 0.11 \mathrm{a}$ & $1.87 \pm 0.00 b$ & $39.21 \pm 1.85 \mathrm{a}$ & $213.45 \pm 3.88 \mathrm{a}$ \\
\hline $4 \mathrm{~min}$ & $15.38 \pm 0.00 \mathrm{~d}$ & $32.31 \pm 0.10 b$ & $9.10 \pm 0.93 a$ & $2.50 \pm 0.00 \mathrm{a}$ & $40.71 \pm 1.02 \mathrm{a}$ & $219.41 \pm 2.81 \mathrm{a}$ \\
\hline $6 \min$ & $16.18 \pm 0.57 \mathrm{c}$ & $34.80 \pm 0.51 \mathrm{a}$ & $7.06 \pm 0.00 b$ & $2.57 \pm 0.00 \mathrm{a}$ & $39.39 \pm 3.51 \mathrm{a}$ & $217.99 \pm 2.55 \mathrm{a}$ \\
\hline \multicolumn{7}{|c|}{ M. arboreus } \\
\hline Raw & $11.73 \pm 0.76 a$ & $12.19 \pm 0.73 b$ & $16.95 \pm 0.05 a$ & $1.47 \pm 0.02 \mathrm{~d}$ & $56.70 \pm 1.74 b$ & $259.5 \pm 5.26 c$ \\
\hline $2 \mathrm{~min}$ & $10.31 \pm 0.54 b$ & $13.59 \pm 1.99 \mathrm{a}$ & $13.96 \pm 0.00 b$ & $1.90 \pm 0.00 c$ & $60.24 \pm 1.99 a$ & $283.33 \pm 7.11 \mathrm{a}$ \\
\hline $4 \min$ & $9.94 \pm 0.08 b$ & $13.86 \pm 1.92 \mathrm{a}$ & $13.79 \pm 1.36 b$ & $2.31 \pm 0.00 b$ & $60.10 \pm 0.55 a$ & $280.86 \pm 5.30 \mathrm{a}$ \\
\hline $6 \mathrm{~min}$ & $9.45 \pm 1.63 b$ & $14.75 \pm 1.06 \mathrm{a}$ & $13.78 \pm 0.25 b$ & $3.43 \pm 0.00 \mathrm{a}$ & $58.59 \pm 0.81 \mathrm{a}$ & $275.31 \pm 3.49 b$ \\
\hline
\end{tabular}

Data are represented as Means \pm SD $(n=3)$. Means in the column with no common letter differ significantly ( $p<0.05)$ for each leafy vegetable.

Table 2. Mineral composition ( $\mathrm{mg} / 100 \mathrm{~g})$ of raw and roasted leafy vegetables consumed in Western Côte d'Ivoire.

\begin{tabular}{|c|c|c|c|c|c|c|c|}
\hline & $\mathbf{C a}$ & Mg & $\mathbf{P}$ & $\mathbf{K}$ & $\mathbf{F e}$ & $\mathrm{Na}$ & Zn \\
\hline \multicolumn{8}{|c|}{ A. esculentus } \\
\hline Raw & $468.45 \pm 0.55 a$ & $364.11 \pm 0.43 \mathrm{a}$ & $671.50 \pm 0.79 a$ & $1844.25 \pm 8.22 \mathrm{a}$ & $130.95 \pm 0.15 a$ & $35.76 \pm 0.04 \mathrm{a}$ & $41.45 \pm 0.04 \mathrm{a}$ \\
\hline $2 \min$ & $448.98 \pm 5.15 b$ & $282.39 \pm 2.91 b$ & $280.53 \pm 2.90 \mathrm{~b}$ & $1480.52 \pm 5.29 \mathrm{~b}$ & $48.28 \pm 0.50 \mathrm{~b}$ & $27.93 \pm 0.29 b$ & $40.13 \pm 0.48 a$ \\
\hline $4 \min$ & $402.34 \pm 3.48 c$ & $280.39 \pm 7.66 b$ & $278.07 \pm 7.73 b$ & $1330.77 \pm 4.06 \mathrm{c}$ & $45.18 \pm 1.48 c$ & $24.93 \pm 0.94 \mathrm{c}$ & $39.77 \pm 1.15 b$ \\
\hline $6 \min$ & $401.86 \pm 4.63 \mathrm{c}$ & $260.92 \pm 2.96 c$ & $272.06 \pm 3.51 \mathrm{~b}$ & $1320.64 \pm 8.49 \mathrm{c}$ & $36.35 \pm 2.80 \mathrm{~d}$ & $17.84 \pm 1.38 \mathrm{~d}$ & $38.39 \pm 1.91 b$ \\
\hline \multicolumn{8}{|c|}{ M.esculenta } \\
\hline Raw & $296.66 \pm 0.46 a$ & $229.45 \pm 0.35 a$ & $759.81 \pm 1.18 \mathrm{a}$ & $2306.09 \pm 3.61 \mathrm{a}$ & $48.69 \pm 0.07 \mathrm{a}$ & $18.30 \pm 0.02 \mathrm{a}$ & $45.48 \pm 0.31 \mathrm{a}$ \\
\hline $2 \min$ & $202.45 \pm 3.70 b$ & $123.73 \pm 2.59 b$ & $263.94 \pm 4.93 b$ & $1917.1 \pm 5.65 b$ & $46.75 \pm 3.44 a$ & $12.01 \pm 3.66 \mathrm{~b}$ & $23.73 \pm 3.95 b$ \\
\hline $4 \mathrm{~min}$ & $201.42 \pm 2.98 b$ & $119.87 \pm 3.56 b$ & $241.05 \pm 7.15 \mathrm{c}$ & $1071.49 \pm 3.79 \mathrm{c}$ & $42.85 \pm 1.57 b$ & $8.28 \pm 1.13 c$ & $21.15 \pm 0.72 b$ \\
\hline
\end{tabular}




\begin{tabular}{llllllll}
\hline & $\mathbf{C a}$ & $\mathbf{M g}$ & $\mathbf{P}$ & $\mathbf{K}$ & $\mathbf{F e}$ & $\mathbf{N a}$ & $\mathbf{Z n}$ \\
\hline 6 min & $198.87 \pm 5.93 \mathrm{c}$ & $110.13 \pm 3.26 \mathrm{c}$ & $224.36 \pm 7.17 \mathrm{~d}$ & $1050.8 \pm 8.50 \mathrm{~d}$ & $42.86 \pm 1.43 \mathrm{~b}$ & $5.98 \pm 0.92 \mathrm{~d}$ & $19.85 \pm 0.70 \mathrm{c}$ \\
I. batatas & & & & & & \\
Raw & $898.83 \pm 0.53 \mathrm{a}$ & $501.75 \pm 0.30 \mathrm{a}$ & $494.76 \pm 0.29 \mathrm{a}$ & $1377.81 \pm 0.22 \mathrm{a}$ & $53.54 \pm 0.03 \mathrm{a}$ & $404.30 \pm 3.62 \mathrm{a}$ & $30.10 \pm 0.01 \mathrm{a}$ \\
$2 \mathrm{~min}$ & $256.81 \pm 3.11 \mathrm{~b}$ & $149.49 \pm 1.74 \mathrm{~b}$ & $182.04 \pm 2.21 \mathrm{~b}$ & $1209.85 \pm 9.51 \mathrm{~b}$ & $44.72 \pm 1.75 \mathrm{~b}$ & $70.29 \pm 0.85 \mathrm{~b}$ & $6.35 \pm 0.07 \mathrm{~b}$ \\
$4 \mathrm{~min}$ & $246.67 \pm 4.34 \mathrm{~b}$ & $139.65 \pm 2.36 \mathrm{c}$ & $174.26 \pm 2.94 \mathrm{c}$ & $1122.77 \pm 7.43 \mathrm{c}$ & $42.80 \pm 2.50 \mathrm{~b}$ & $52.25 \pm 0.88 \mathrm{c}$ & $4.29 \pm 0.07 \mathrm{~b}$ \\
6 min & $235.48 \pm 2.70 \mathrm{c}$ & $123.13 \pm 1.41 \mathrm{~d}$ & $170.39 \pm 1.96 \mathrm{c}$ & $1056.75 \pm 9.02 \mathrm{~d}$ & $38.75 \pm 1.13 \mathrm{c}$ & $20.40 \pm 0.23 \mathrm{~d}$ & $4.15 \pm 0.14 \mathrm{~b}$ \\
C. argentea & & & & & & \\
Raw & $788.02 \pm 0.50 \mathrm{a}$ & $981.31 \pm 0.62 \mathrm{a}$ & $650.37 \pm 0.41 \mathrm{a}$ & $4987.15 \pm 3.19 \mathrm{a}$ & $285.31 \pm 0.18 \mathrm{a}$ & $42.26 \pm 0.02 \mathrm{a}$ & $62.01 \pm 0.03 \mathrm{a}$ \\
2 min & $542.06 \pm 2.05 \mathrm{~b}$ & $467.43 \pm 8.15 \mathrm{~b}$ & $384.56 \pm 4.93 \mathrm{~b}$ & $3796.16 \pm 7.42 \mathrm{~b}$ & $128.47 \pm 4.99 \mathrm{~b}$ & $40.78 \pm 2.74 \mathrm{a}$ & $24.68 \pm 0.96 \mathrm{~b}$ \\
4 min & $499.13 \pm 1.60 \mathrm{c}$ & $431.56 \pm 1.39 \mathrm{c}$ & $274.64 \pm 5.06 \mathrm{c}$ & $3448.92 \pm 1.07 \mathrm{c}$ & $118.12 \pm 0.37 \mathrm{c}$ & $34.42 \pm 0.14 \mathrm{~b}$ & $22.18 \pm 0.08 \mathrm{c}$ \\
6 min & $394.15 \pm 0.03 \mathrm{~d}$ & $419.67 \pm 0.01 \mathrm{~d}$ & $260.57 \pm 2.61 \mathrm{~d}$ & $3067.20 \pm 1.20 \mathrm{~d}$ & $93.78 \pm 1.50 \mathrm{~d}$ & $25.56 \pm 2.50 \mathrm{c}$ & $20.48 \pm 0.01 \mathrm{~d}$ \\
$M$. arboreus & & & & & & \\
Raw & $436.64 \pm 0.52 \mathrm{a}$ & $354.23 \pm 0.42 \mathrm{a}$ & $283.19 \pm 0.34 \mathrm{a}$ & $2350.58 \pm 2.83 \mathrm{a}$ & $79.54 \pm 0.09 \mathrm{a}$ & $20.83 \pm 0.02 \mathrm{a}$ & $75.20 \pm 0.09 \mathrm{a}$ \\
2 min & $326.40 \pm 7.25 \mathrm{~b}$ & $263.50 \pm 3.92 \mathrm{~b}$ & $175.19 \pm 9.26 \mathrm{~b}$ & $1648.94 \pm 7.12 \mathrm{~b}$ & $72.40 \pm 5.41 \mathrm{~b}$ & $16.70 \pm 2.47 \mathrm{~b}$ & $27.00 \pm 1.43 \mathrm{~b}$ \\
4 min & $278.98 \pm 2.38 \mathrm{c}$ & $215.23 \pm 1.84 \mathrm{c}$ & $160.10 \pm 1.87 \mathrm{c}$ & $1253.61 \pm 1.70 \mathrm{c}$ & $70.50 \pm 0.67 \mathrm{~b}$ & $11.58 \pm 0.44 \mathrm{c}$ & $22.36 \pm 0.19 \mathrm{c}$ \\
6 min & $224.83 \pm 6.14 \mathrm{~d}$ & $203.40 \pm 3.60 \mathrm{~d}$ & $153.01 \pm 1.39 \mathrm{~d}$ & $1071.74 \pm 7.45 \mathrm{~d}$ & $63.43 \pm 3.27 \mathrm{c}$ & $9.70 \pm 6.78 \mathrm{~d}$ & $20.38 \pm 3.46 \mathrm{~d}$ \\
\hline
\end{tabular}

Data are represented as Means $\pm \mathrm{SD}(\mathrm{n}=3)$. Means in the column with no common letter differ significantly $(\mathrm{p}<0.05)$ for each leafy vegetable.
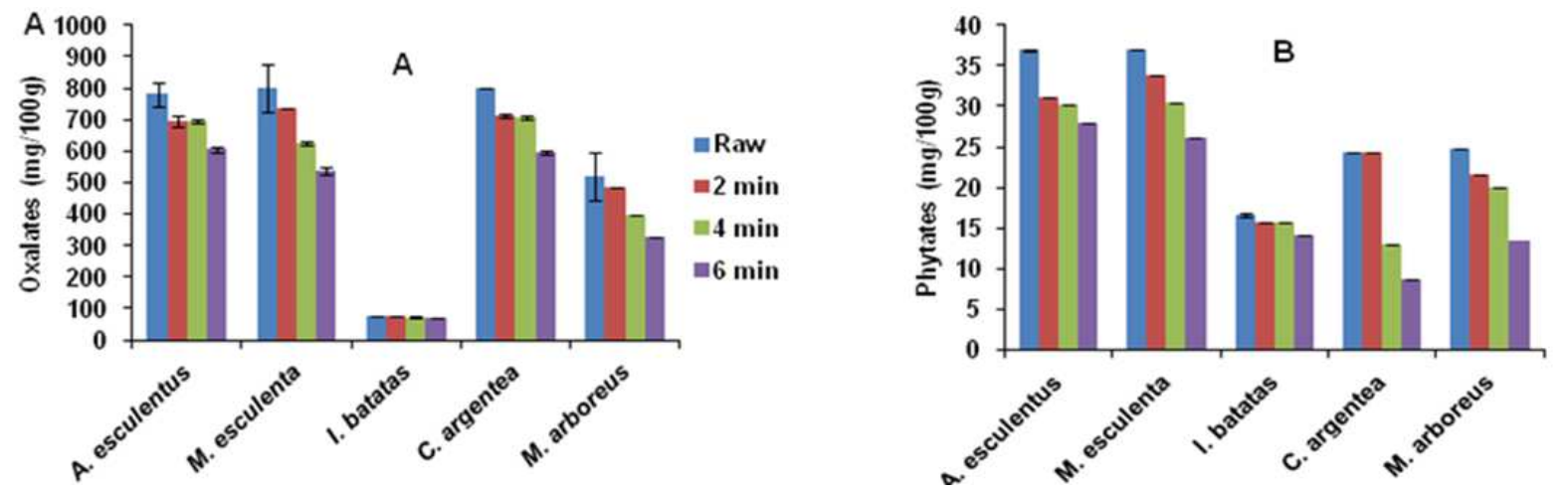

Figure 1. Oxalate $(A)$ and phytate $(B)$ contents of raw and roasted leafy vegetables consumed in Western Côte d'Ivoire.

Table 3. Anti-nutritional factors/mineral ratios of raw and roasted leafy vegetables consumed in Western Côte d'Ivoire.

\begin{tabular}{llll}
\hline & Phytates/Ca & Phytates/Fe & Oxalates/Ca \\
\hline A. esculentus & & & \\
Raw & 0.07 & 0.28 & 1.66 \\
2 min & 0.10 & 1.04 & 1.56 \\
4 min & 0.08 & 0.74 & 1.37 \\
6 min & 0.07 & 0.67 & 1.22 \\
M.esculenta & & & \\
Raw & 0.12 & 0.75 & 2.69 \\
2 min & 0.36 & 1.30 & 3.64 \\
4 min & 0.32 & 1.25 & 3.15 \\
6 min & 0.28 & 1.06 & 2.71 \\
I. batatas & & & \\
Raw & 0.01 & 0.31 & 0.08 \\
2 min & 0.14 & 0.26 & 2.41 \\
4 min & 0.13 & 0.24 & 1.84 \\
6 min & 0.14 & 0.34 & 1.72 \\
C. argentea & & & \\
Raw & 0.03 & 0.08 & 1.01 \\
2 min & 0.06 & 0.26 & 1.50 \\
4 min & 0.02 & 0.11 & 1.43 \\
6 min & 0.01 & 0.10 & 1.35 \\
M. arboreus & & 0.31 & 1.01 \\
Raw & 0.05 & 0.46 & \\
2 min & 0.20 & & \\
4 min & 0.22 & 0.80 & \\
6 min & 0.13 & & \\
\hline & & & \\
\hline
\end{tabular}

\subsection{Antioxidant Properties}
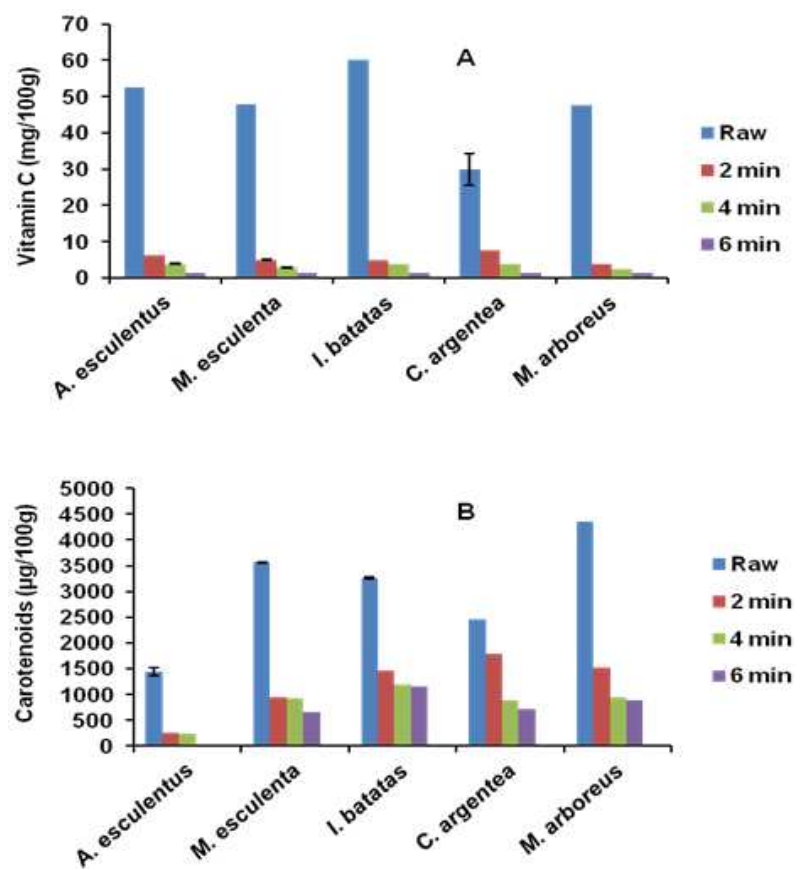

Figure 2. Vitamin $C(A)$ and carotenoid $(B)$ contents of raw and roasted leafy vegetables consumed in Western Côte d'Ivoire 


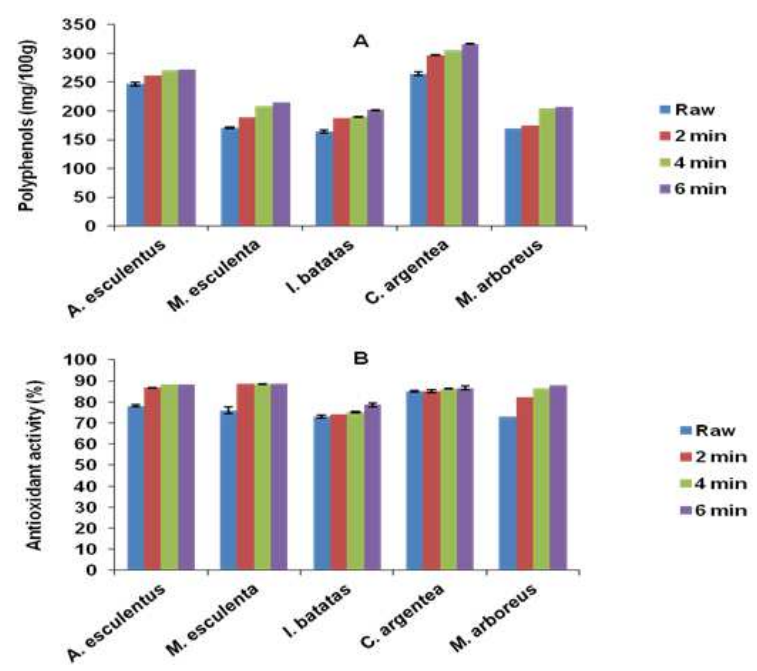

Figure 3. Polyphenol contents (A) and antioxidant activity (B) of raw and roasted leafy vegetables consumed in Western Côte d'Ivoire

Roasting also resulted in decrease of carotenoids and vitamin $\mathrm{C}$ contents in the studied leafy vegetables (Figure 2 ). For carotenoids, losses at 2 min ranged from $27.37 \%$ (C. argentea) to $81.94 \%$ (A. esculentus). These losses are slightly lower than those $(87-100 \%)$ obtained for the same boiled leafy vegetables [26]. The decrease of total carotenoids could be attributed to the oxidation and isomerization of $\beta$-carotene [39]. For vitamin $\mathrm{C}$ content, a significant reduction (75 92.14\%) was highlighted after 2 min during roasting processing (Figure 2). The reduction of vitamin $\mathrm{C}$ in this study was lower than that $(50-84 \%)$ obtained for boiling processing [26]. This decrease in vitamin $\mathrm{C}$ could be attributed to the fact that vitamin $\mathrm{C}$ is not stable at high temperature [40]. With regard to the vitamin $\mathrm{C}$ decrease, consumption of roasted leafy vegetables may be supplemented with other sources of vitamin $\mathrm{C}$ such as tropical fruits to cover the daily need for humans $(40 \mathrm{mg} /$ day $)$ as recommended by food agriculture organization [34].

The effect of roasting on polyphenols content and antioxidant activity of the selected leafy vegetables is depicted in figure 3. It was observed a relatively high increase of polyphenols contents varying from 2.63 to $13.83 \%$. The percent gain in the total phenols contents during blanching may be due to the release of phenolic compounds trapped in the fibres of leafy vegetables [41]. Therefore, consumption of drinks prepared with powdered roasted leafy vegetables could be advantageous for lower cellular ageing process in human body because polyphenols are known for their antioxidant and scavenging properties $[42,43]$.

\section{Conclusion}

Leafy vegetables used for sauce preparation that accompany starchy foods in Western Côte d'Ivoire highlighted a potential of nutrients that are essential for human health. The aim of this work was to investigate the impact of roasting processing on the nutritive and antioxidant properties of these leafy vegetables. The results obtained showed that roasting processing decreases to a lesser extent the contents of proteins, minerals, vitamin $\mathrm{C}$, carotenoids, and anti-nutritional factors (oxalates and phytates) but increases their antioxidant activity. The reduction of anti-nutritional factors and the increase of polyphenols content might have a beneficial effect on health consumers. In order to contribute efficiently to the nutritional requirement and to the food security of Ivoirian population, the recommended time of roasting leafy vegetables must be less than $2 \mathrm{~min}$. However, roasting processing must be compared with other cooking methods as blanching and boiling in the same experiment conditions. In addition, sensorial analysis of roasted leafy vegetables must be performed in order to appreciate their palatability.

\section{References}

[1] Voster, I.H.J., Van-Rensburg, W.J., Van Zijl, J. and Venter, S.L. (2007). The importance of traditional leafy vegetables in South Africa. AJFAND, 7: 1-13.

[2] Uusiku, N.P., Oelofse, A., Duodu, K.G.., Bester, M.J. and Faber, M. (2010). Nutritional value of leafy vegetables of sub-Saharan Africa and their potential contribution to human health: A review. J. Food Comp. Anal., 23:499-509.

[3] Termote, C., Van Damme, P. and Dhed'a, B. (2011). Eating from the wild: Turumbu, Mbole and Bali traditional knowledge on non-cultivated edible plants, district Tshopo, DR Congo. Genetic Res. Crop Evol., 58:585-618.

[4] Chweya, J.A. and Eyzaguirre, P.B. (1999). The biodiversity of traditional leafy vegetables. International Plant Genetics Resources Institute. Rome.

[5] Kubo, I., Fijita, K., Kubo, A., Nehi, K. and Gura, T. (2004). Antibacterial activity of coriander volatile compounds against Salmonella choleraesuis. J. Agric. Food Chem., 52:3329-3332.

[6] Maziya-Dixon, B., Akinyele, I.O., Oguntona, E.B., Nokoe, S., Sanusi, R.A. and Harris, E. (2004). Nigeria Food Consumption and Nutrition Survey. IITA, Ibadan, Nigeria.

[7] Harrison, J.A. and Andress, E.L. (2000). Preserving food: Drying Fruits and Vegetables. University of Georgia. Cooperative Service.

[8] PROTA (2004). Ressources végétales de l'Afrique tropicale. Volume 2: Légumes. Grubben G.J.H. et Denton O.A. (eds). Fondation PROTA / Backhuys Publishers / CTA, Wageningen. $737 \mathrm{p}$.

[9] Fondio, L., Kouamé, C., N'zi, J.C., Mahyao, A., Agbo, E. and Djidji A.H. (2007). Survey of indigenous leafy vegetable in the urban and peri-urban areas of Côte d'Ivoire. Acta Hort., 752: 287-289.

[10] Soro, L.C., Atchibri, L.O., Kouadio, K.K. and Kouamé, C. (2012). Evaluation de la composition nutritionnelle des légumes-feuilles. J. Appl. Biosci., 51:3567- 3573.

[11] Zoro, A.F., Zoue, L.T., Kra, A.K., Yepie, A.E. and Niamke S.L. (2013). An overview of nutritive potential of leafy vegetables consumed in Western Côte d'Ivoire. Pak. J. Nutr. 12:949-956.

[12] Canet W. (1989). Quality and stability of frozen vegetables. In S. Thorne (Ed.). Developments in food preservation (Vol. 5). New York: Elsevier Science Publishing Inc. 
[13] Prestamo, G., Fuster, C. and Risueno, M.C. (1998). Effects of blanching and freezing on the structure of carrots cells and their implications for food processing. J. Sci. Food Agric., 77: 223-229.

[14] Murcia, M.A., Lopez-Ayerra, B. and Garcia-Carmona F. (1999). Effect of processing methods and different blanching times on broccoli: proximate composition and fatty acids. Lebensmittel-Wissenschaft Technol. 32:238-243.

[15] Oboh, G. (2005). Effect of blanching on the antioxidant properties of some tropical green leafy vegetables. Lebensmittel-Wissenschaft Technol. 38:513-517.

[16] Chinma, C.E. and Igyor, M.A. (2007). Micro-nutriments and anti-nutritional content of select tropical vegetables grown in South-East, Nigeria. Nig. Food J., 25:111-115.

[17] AOAC (1990). Official methods of analysis. Association of Official Analytical Chemists Ed., Washington DC. 684 p.

[18] FAO (2002). Food energy-methods of analysis and conversion factors. FAO Ed, Rome. 97 p.

[19] CEAEQ (2013). Mineral determination. Argon plasma spectrometry method. MA 200 - Met 1.2, Rev 4. Quebec, 24 p.

[20] Day, R.A. and Underwood, A.L. (1986). Quantitative analysis. $5^{\text {th }}$ ed. Prentice Hall. 701 p.

[21] Latta, M. and Eskin, M. (1980). A simple method for phytate determination. J. Agric. Food Chem. 28:1313-1315.

[22] Pongracz, G.., Weiser, H. and Matzinger, D. (1971). Tocopherols- Antioxydant. Fat Sci. Technol. 97:90-104.

[23] Rodriguez-Amaya, D.B. (2001). A guide to carotenoids analysis in foods. ILSI Press, Washington DC. 64 p.

[24] Singleton, V.L., Orthofer, R. and Lamuela-Raventos, R.M. (1999). Analysis of total phenols and other oxydant substrates and antioxydants by means of Folin-ciocalteu reagent. Methods Enzymol. 299:152-178.

[25] Choi, C.W., Kim, S.C., Hwang S.S., Choi B.K., Ahn H.J., Lee M.Z., Park S.H. and Kim S.K. (2002). Antioxydant activity and free radical scavenging capacity between Korean medicinal plant and flavonoids by assay guided comparison. Plant Sci. 163:1161-1168.

[26] Zoro, A.F, Zoue, L.T., Bedikou, M.E., Kra A.S. and Niamke L.S. (2014). Effect of cooking on nutritive and antioxidant characteristics of leafy vegetables consumed in Western Côte d'Ivoire. Arch. Appl. Sci. Res. 6:114-123.

[27] Lund, D.B. (1997). Effects of heat processing on nutrients. In: Nutritional Evaluation of Food Processing, (R. Harries and E. Karmas, eds). The AVI Publishing Co. Inc Westport. p. 205 - 203.

[28] Gibson, R.S., Perlas, L. and Hotz, C. (2006). Improving the bioavailability of nutrients in plant foods at the household level. Proceedings Nutr. Soc., 65:160-168.
[29] Svanberg, S.M., Nyman, E.M., Andersson, L. and Nilsson, R. (1997). Effects of boiling and storage on dietary fiber and digestible carbohydrates in various cultivars of carrots. J. Sci. Food Agric., 73:245-254.

[30] Ishida, H., Suzuno, H., Sugiyama, N., Innami, S., Todokoro T. and Maekawa A. (2000). Nutritional evaluation of chemical component of leaves stalks and stems of sweet potatoes (Ipomea batatas). Food Chem., 68:359-367.

[31] Ejoh, A.R., Tchouanguep, M.F. and Fokou, E. (1996). Nutrient composition of the leaves and flowers of Colocasia esculenta and the fruits of Solanum melongena. Plant Food Hum. Nutr., 49: 107-112.

[32] Sobowale, S.S., Olatidoye, O.P., Olorode O.O. and Akinlotan J.V. (2011). Nutritional potentials and chemical value of some tropical leafy vegetables consumed in south west Nigeria J. Sci. Multidisciplinary Res., 3:55-65.

[33] Sandberg, A.S. (2002). Bioavailability of minerals in legumes. Brit. J. Nutr., 88:281-285.

[34] FAO (2004). Human vitamin and mineral requirements. FAO Ed. 361p.

[35] Turan, M., Kordali, S., Zengin, H., Dursun, A. and Sezen Y. (2003). Macro and micro-mineral content of some wild edible leaves consumed in Eastern Anatolia. Plant Soil Sci. 53: 129-137.

[36] Chaturvedi, V.C., Shrivastava, R. and Upreti, R.K. (2004). Viral infections and trace elements: A complex trace element. Curr. Sci., 87:1536-1554.

[37] Trowbridge, F. and Martorell, M. (2002). Forging effective strategies to combat iron deficiency. J. Nutri. 85:875-880.

[38] Hassan, L.G.., Umar, K.J. and Umar, Z. (2007). Anti-nutritive factors in Tribulus terrestris (Linn) leaves and predicted calcium and zinc bioavailability. J. Trop. Biosci. 7:33-36.

[39] Speek, A.J., Temalilwa, G.R. and Schrijver J. (1986). Determination of $\beta$-carotene content and vitamin A activity of vegetables by HPLC. Food Chem. 19:65-74.

[40] Nagy, S. and Smooth J.M. (1977). Temperature and storage effects on percent retention and percent U.S. recommended dietary allowances of vitamin $\mathrm{C}$ in canned single-strength orange juice. J. Agric. Food Chem. 25:135-138.

[41] Oboh, G. and Rocha, J.B. (2007). Polyphenols in red pepper and their protective effect on some pro-oxidants induced lipid peroxidation in brain and liver. Eur. Food Res. Technol. 225: 239-247.

[42] Rice-Evans, C. and Miller, N.J. (1995). Antioxidants: the case for fruit and vegetables in the diet. Brit. Food J. 97:35-40.

[43] Amic, D., Davidovic-Amic, D., Beslo, D. and Trinajstic N. (2003). Structure-radical scavenging activity relationship of flavonoids. Croatia Chem. Acta. 76:55-61. 